\title{
Manifesting the Semantic Differences of the Words Love and Affection and Their Derivations in the Glorious Quran
}

\author{
Daad Younus Hussein Abdullah ${ }^{1} \&$ Zulazhan Bin Ab. Halim ${ }^{2}$ \\ ${ }^{1}$ Arabic Language Department, College of Education for Humanities, University of Mosul, Iraq \\ ${ }^{2}$ Arabic Language Department, Faculty of Languages and Communication, Universiti Sultan Zainal Abidin, \\ Malaysia \\ Correspondence: Zulazhan Bin Ab. Halim, Faculty of Languages and Communication, Universiti Sultan Zainal \\ Abidin (UniSZA), Gong Badak Campus, Kuala Nerus, Terengganu, Malaysia. Tel: 60-9668-8023. E-mail: \\ zulazhan@unisza.edu.my
}

Received: June 20, $2018 \quad$ Accepted: November 7, $2018 \quad$ Online Published: November 29, 2018

doi:10.5539/ass.v14n12p176 URL: https://doi.org/10.5539/ass.v14n12p176

\begin{abstract}
This research states the importance of love; that word with tender shadows and the one beloved by the human soul, and Islam reflects a special understanding for this word as it is a religion that acknowledges love as one of the most vital and effective human impulses and motives in the individual and collective behavior. It is also one of the paths to recognize Allah and approach him. There is no doubt that affection is a positive virtue because it is, in essence, a means to approve the bonds of love and intimacy and reviving them even if it represents an emotional and sentimental denotation, though it is originally a positive and practical tendency. Love is the polar of worship as loving the religion and its details is a sign of the faith perfection; loving Allah entails obeying his messenger peace be upon him and his tradition. There is a semantic difference between the two words: love and affection as love is what settled in the heart and affection is what was translated by the behavior and not every loving person is friendly and the human can love and this love does not show in his behavior and every friendly person has affection in his heart and its basis is the love feeling inside his heart, therefore the affection is the love which is not reflected. The current research relied on references that deal with the semantic differences as a partnership study conducted by Mosul University in Iraq and Universiti Sultan Zainal Abidin in Malaysia.
\end{abstract}

Keywords: manifestation, semantic, love, affection, Quran

\section{Introduction}

Arabic language is characterized with having too many synonyms and has being very precise in terms of the meanings of its vocabularies. In this research the two words (love) and (affection), were chosen to manifest the difference in their denotative meanings as they used in the Quranic context as no word can give the exact meaning in the Quranic context in particular and therefore this paper included two parts; the first part represented the theoretical aspect in which the two words were dealt with linguistically and terminologically and showing the relationship between the lexical meanings and the terminological meanings for both (love) and (affection) in addition to identifying the semantic differences for the two words. Part two represented the practical aspect of the study and included two branches; the first tackled the word (love) and in which the statistics of the Quranic verses that included the word love and its derivations which were diversified with a diversity of contexts and resulted in the denotation of love in the verbs and the denotation of (love) in the verbal noun and the superlative form. While the second branch dealt with the word (affection) in which the statistics of the Quranic verses in which the word (affection) and its derivatives were mentioned, and this resulted in the denotation of (affection) in verbs and the denotation in verbal nouns. After that comes the conclusion which displays the most important findings of the research.

This topic was not studied academically and there are no studies that show the type of relationship between the two words (love) and (affection), except for being mentioned in chapters or section included within university thesis and dissertations, books or other studies that dealt with this subject. The following are some of the studies which are relevant to the topic of the paper. Dawood M. M. (2008) has briefly mentioned the semantic differences between the words (love) and (affection). This study dealt with the vocabularies of love, passion, inclination and affection and he stated the their lexical differences in addition to shifting with the word from the 
tangible abstractive meaning to the intangible meaning and then comparing the similar words through the various Quranic contexts. A study mentioned the different forms of the word and its diversity between verbs, verbal nouns and derivatives in the holy Quran with mentioning an example for each type (Yaseen, 2009). A study tackled the subject in accordance with the objective interpretation of the holy Quran (Al-Sharafi, 2014). Another study tackled the morals that Islam calls people have to satisfy Almighty Allah and to establish a humanitarian civilization that is based on the supreme values (Al-Thallab, 2014).

\section{Methodology}

The study impairs both the library, methodological study and the semantic analysis in the modern scientific research through the following steps including firstly the reviewing the previous studies to identify the semantic differences between the two words; love and affection and their derivations in the glorious Quran and their integration with the logical beliefs of the researcher in order to outline the linguistic, terminological, grammatical and the philological differences referring to the theoretical framework and the references as well as the experience of the researcher to manifest those differences. Secondly, calculation of the Quranic verses in which the two words; love and affection, their derivations, classifications and formulating the finding of the study academically.

\section{Results and Discussion}

\subsection{Love and Its Derivations, Concept and Semantic Meaning}

\section{1 .1}

Love means accompanying and stability, and also means (in Arabic) the seed of a plant with seeds. The third meaning (Ibn Faris, 2008). The word (Habb) means wheat and barley, the habbat AlQalb means its core or its fruit, which is the black leech inside the heart. It is said so is the core of his heart which means his beloved and that his heart is full of love to her. For the meaning "accompanying" is derived from love where someone accompanies someone else forever, and the origin of the word is the camel which stays in its place and never moves (Ibn Manthoor, 2003). Love also means the beloved person. Zaid Ibn Haritha (may Allah be pleased with him) was called the beloved of prophet Mohammed peace be upon him which means the person whom he loves. Also (Hubb) means the vessel in which drinking water is kept, and love is the opposite of hatred while the (Habbab) means the arrangement of the human teeth but (Hibbab) means the water on the teeth or that touches them.

\section{1 .2}

Love is the attraction to something one loves and love also is the willing to what one sees or think good. It involves three aspects: love of pleasure such as when the man loves a woman, love the benefit and love of virtue and favor as when scholars love each other (AlAsfahani, 1992). Love has no limits to something or someone the soul feels comfortable with and wish to do it" (AlSharawi, 1997). Love has no limits which are clearer than it and limits make it more invisible. Therefore its limit is its existence. The word in Arabic consists of two letters (Haa and Baa) which are so suitable: the sound Haa is articulated from the end of the throat and the sound Baa is pronounced by the lips so it means the beginning and the end and this is evident in love as it begins and ends altogether. The word love (Hubb) is pronounced with the (Thammah) which is the strongest circumflex in Arabic to denote the strength of love between the lover and the beloved and for the frequent mention of the beloved (AlFairooz Abadi, 1966).

\section{1 .3}

Through detecting the linguistic and the terminological meanings of love, it was shown that there is a relationship between them as the terminological meaning is pivoting on the linguistic material meaning which is sensed. The word "love" tackles five things (meanings): accompanying, persistence and willingness, and it is derived from the camel act (Ahab'ba) which means stayed in its place and didn't stand as if he loves the place in which he stays. It also means the willingness as it is willing to have what you believe is good and it also means the whiteness and pureness related to the teeth which are white and beautiful. It also means elevation and triumphant this is derived from the raindrops and the bubbles caused by them, (Hibab) is the water that touches the teeth, Habbat AlQalb means its core and the essence of everything which is derived from the (Habbah = seed) which is the origin and the substance. There is no doubt that these meanings are involved in love as it is the pureness and upheaval of the willingness of the heart and it is supreme and triumphed because it is tightly related to the beloved. The persistence of the heart willingness to the beloved without abandonment or separation, and because the person gives his beloved one his mind and the noblest thing he has which is his heart, the five meanings were included in the word (AlFairouzAbadi, 1966). 


\subsection{4}

The root "love" and its derivations was mentioned in the glorious Quran eighty three times in seventy four verses (Ibrahim, 2009) and in different forms including verbs and nouns as well as some derivatives and as follows: it came as verbs so many times especially in the present tense which denotes renewal and continuity and past tense that confirms the action (AlSamuraee, 2015). "As for the commanding form of "love", which means the future, it was never mentioned in the Quran because love is something innate, coming from the heart and it is impossible for love to be something achieved by a command or request" (AlSharafi, 2014). The following are the types of (love) forms and its derivations and arrangement per the frequency: present tense (I love, he loves, you love, they desire, he loves you, they love him, you love), the past tense: (made you like, they desired, I loved), the superlative (most desirable), the noun (love, his desire) and the plural (His beloved).

\section{1 .5}

Almighty Allah says ((Say, [O Muhammad], "If you should love Allah, then follow me, [so] Allah will love you and forgive you your sins. And Allah is Forgiving and Merciful)) (Aalu Imran: 31). In this verses we notice an invitation to the people to believe in Allah. We see that Allah directed the humans to believe in Him and in His messengers by means of threats, at the same time Almighty Allah calls them to do that from another perspective, as the Jews used to say: ((But the Jews and the Christians say, "We are the children of Allah and His beloved." Say, "Then why does He punish you for your sins?" Rather, you are human beings from among those He has created. He forgives whom He wills, and He punishes whom He wills. And to Allah belongs the dominion of the heavens and the earth and whatever is between them, and to Him is the [final] destination)) (AlMa'ida: 18). It is also narrated that the Christians used to say: we glorify Jesus Christ as an expression of our love to Allah, and this was also the reply of Quraish to prophet Mohammed (PBUH), when he spoke to Quraish while they were in the holy house prostrating to the idols, he said: O people of Quraish, I swear by Allah that you have broken the teachings of Abraham's religion. The crowd replied: We worship the idols because we love Allah, they make us closer to Him. We see that each of these sects claim that it loves Allah and seeks His satisfaction, and for this reason this verse was revealed and it stipulates that whoever loves Almighty Allah must be very cautious of what incur his wrath. As there has been an absolute proof about the prophecy of prophet Mohammed (PBUH), so he should be obeyed and if not, that means love doesn't take place, and because love and willing are the same and willing is only related with the events and benefits this will be not correct as nothing can be said about everything that it is loved for another meaning and the thing should be loved per se as we love the enjoyment for itself. The optimum perfection is confined to Almighty Allah and that entails that He should be loved for Himself, while loving the slave (person) by Allah represents the will of Allah to provide him with good things and benefits in this world in terms of his religion and his life (Fakhr AlDeen AlRazi, 1999). Therefore, loving the human beings is a metaphor of their will to worship Allah only and no one but Allah and Allah's love to the human is represented by being contented with their deeds and praise them (AlZamakhshari, 1987). The human is the creation of Allah and He created him, aided him and assigned to him certain duties. So, Allah made the assignment at the service of the creation and the aid and if He didn't make the life motion system represented by the commandments (do this) and (don't do that) the creation and aid would be of no use. His perfect blessing to the people (creation) was represented by founding the assignment which seems to be wearing to the human and so he ignore it and then it will be not enough to love Allah for the blessing of creating and aiding you, because in this case you become neglecting to the assignment blessing that leads to your good being, therefore never ignore it as Allah's love to his slave is associated with the human's knowledge about the blessing of assignment. Those who claim that they love Allah because they are the slaves of His blessing in terms of Being their creator and their helper cannot fulfill their assignments and this way they cancel half of the love to Allah because in the assignment is the goodness of creation and support. Love is the affection of the heart and if we measure it we can notice its effects represented by the forgiveness, mercy and satisfaction and it is measured by the obedience to Allah. Almighty Allah demand the love affection with the affection of the heart where the human does his assignments as a representation of obedience and love to Allah and in return he will gain Allah's love represented by His forgiveness, mercy and satisfaction. Loving Allah in the assignment is the mental love and we should distinguish between the mental and the emotional love, as the emotional love has no rule because a man loves his son even if he is not very clever or he loves him by his passion and hates the person with low cleverness. The human feels the bitter medicine in his feeling but considers it sweet in his mind and so he loves it. Therefore Allah's assignment for faith is loved by the human's mind and after that this love sublimes to become a passionate love and therefore Allah says ((If you love Allah then follow me so that Allah will love you)) and this love is not a pretence. Following is shown in the behavior, when we adhere to the messenger of Allah then we are accepting Allah's assignment as a blessing in spite of its difficulties and in return Allah will love us as we 
preferred to fulfill His assignment as a blessing and accept it as a blessing in spite of its difficulties and love of Allah will be the reward. In this way heart enjoyment takes place by recognizing the honorable divine affairs which are hard to be attained by the ordinary senses and the human sound mind and nature will tend to them and thus love becomes meaningful when there will be a tendency to gain the enjoyment (AlShaarawi, 1997).

\section{1 .6}

Almighty Allah says: ((Do not stand [for prayer] within it - ever. A mosque founded on righteousness from the first day is more worthy for you to stand in. Within it are men who love to purify themselves; and Allah loves those who purify themselves.)) (AlTauba: 108). In this noble verse, the gerund (bنطرين = who purify themselves) which is derived from the root (purify - طُهُ ) was mentioned in the intangible matters and this form of the gerund denotes demanding something urgently and persistently (AlSameeri, 2002). So, we see these men who were mentioned as doing this assignment are desiring to satisfy Allah. From the other hand the word (منطرين = puritans) is used for the senses issues and this was the reason why the verb (Yatataharo) and the gerund (Mutatahireen) were both used. This is a sign from Allah in which He calm the human that whoever believes will be aided by Allah and will be flooded with tangible and intangible goodness and the person who is pure will be enjoying the floods of goodness from Allah to him. Therefore, correct the orientation of your receiver by purifying yourself from any impurity tangible of intangible. When you see a man who is overwhelmed with right, you should know that all the particles of his body is constructed by Halal gain and without any intangible dirtiness nor tangible dirtiness and all this is noticed on his face, words and his good reception. The goodness floods are gained by purifying the soul, and if the human lacked them, then he should search in his receiver. For instance, the broadcasting stations transmits and the people who have a good receiver will receive this broadcast, but if the receiver is corrupt, no reception will be there and for this reason Almighty Allah says: ((Rather, both His hands are extended)) (AlMaidah: 64). So, be keen to get the endless aid from your Lord (AlShaarawi, 1997). What was mentioned in Ibn Majah Sunnan, narrated by Anas Ibn Malik: these verse was descended and specified to Qubaa mosque people who were cleaning themselves using water and stones to rationalize the use of water at that time: ((Within it are men who love to purify themselves; and Allah loves those who purify themselves.)), Anas says, the prophet of Allah asked: (O people of Ansar, Allah has praised you as puritans, how do you purify? They said: we conduct ablution, wash our bodies (from Janab = after intercourse) and cleaning ourselves with water. He said: that the right thing to do, keep on doing it). The word mosque means the prophet's mosque (PBUH) and the meaning of "established on piety basis" means from the first day it was constructed which is the first day in which the prophet enters AlMadeenah (AlAloosi, 1995), which is considered the first day of the Islamic history. Allah loves the person who purify themselves means be pleased with them, be generous with them and maximizes their rewards and this is what is meant by loving Allah and those persons were described as ones who love to be purified as the reason behind purification is getting rid of the wrongdoings and bad features as conditions to love Allah. The matter here is not the construction of the mosque, but rather about the men who enter it and construct it, and the meaning of love is the tendency of the human nature to the thing that the soul relieves with and does it eagerly (AlShaarawi, 1997).

\section{1 .7}

Everything Allah commanded the people to do it represents the good for them and the souls love it and the things Allah commanded the people to avoid are hated originally by the souls of the people because the sound psychological constructs are programmed by the Great Creator to love the things He ordered the people to love and to hate what He ordered the people to avoid (AlNabulsi, 2009). The evidence is what Almighty Allah says: ((And know that among you is the Messenger of Allah. If he were to obey you in much of the matter, you would be in difficulty, but Allah has endeared to you the faith and has made it pleasing in your hearts and has made hateful to you disbelief, defiance and disobedience. Those are the [rightly] guided)) (AlHujurat: 7). One of the denotations of the past tense verb is that it denotes the realization as it denotes the happening of something before the time of speaking (Okashah, 2005). It asserts the happening of the action by realizing it. The following is an introduction of what we will clarify about the verbal noun (Hub'ban) and the comparative noun (Ahab'bu) in the noble Quranic verses and all of them were mentioned in the story of prophet Yousuf (PBUH). In the story there are two types of the innate love: the father's love to his son, and the love between the man and the woman. The comparative noun (Ahab'bu) represents a comparison between two or several things and it involves addition of letters to the base verb mostly and the participation in meaning between the two compared parts includes a participation in the meaning which is not reality but estimation (AlSamaraee, 2007). In the verse (he has impassioned her with love), the shighafis the pericardium (membrane that encompasses the heart) and it is called the heart membrane, i.e. a core surrounded like the pericardium surrounds the heart and that means love surrounded her heart and became a screen between her and anything else other than love. She doesn't feel or see 
anyone but him and no one in her mind except him and the exact meaning is that her love to him permeated to the deepest of her heart and this is a metonymy for the vigorous love (Fakhr AlDeen AlRazi, 1999). So, AlShaghaf (شغف = fondness) is feeling a powerful love, that this love penetrates the heart of the human making him suffering and bewildered (Ibrahim, 2009).

\section{1 .8}

Love is classified into stages; the first stage is the fancy which might end at the moment of seeing the beloved and if the human attached to what / whom he sees then he will move from the fancy stage to the amour which is the love attendant at the heart; after that comes the fondness, which means suffering to get what he desires of this relation and then it turns to the rank of meeting which is the passion when the two lovers exchange their feelings manifesting their fondness, after that the rank of Shaghaf in which the heart is burning accompanied with a kind of pleasure, then the lovesickness and intense emotion (the interior love), then the enthrallment (love enslaving), AlTabal (love makes him sick) and then the bewitching of love (when the person hardly remains sane and the body becomes skinny and lastly when one becomes madly in love and so he loses every goal and doesn't know where he is heading. These are the stages and ranks of love through which the heart passes. The human recognizes the things with his senses, and when he recognizes some matters, his mind does the process of balancing between them and then chooses the most acceptable one. After that it goes to the heart to settle there and becomes a non-negotiable ideology, therefore we call the things which settled in the heart ideologies: which means something tight that can never be loosen and if a principle settled in the soul of the human all his actions will be inspired by this principle in which he believes.

\section{1 .9}

The expression (he has impassioned her with love) means that the emotions moved from her perception to her mind and finally to her heart, i.e. love has totally overwhelmed her heart (AlAloosi, 1997), and the speech of the women (we see her [to be] in clear error), is saying the truth with purpose of falsehood and therefore Almighty Allah exposes their intention by saying: ((And when she heard their deceitfulness)) (AlShaarawi, 1997). Saying this is similar to what Yousuf's brothers said: ((Joseph and his brother are more beloved to our father than we, Indeed, our father is in clear error)) and error means far away from the right path and the women expressed by using the present tense verb ((is seeking to seduce her slave boy)) and this means that it became a habit to her trying to seduce him always, so the women mentioned the continuity of her attempts as her love to him was overwhelming and turned to be madness of love (Abu Hayyan AlAndalusi, 1999). AlAzeez wife, after she gathered the women, said ((and if he will not do what I order him, he will surely be imprisoned and will be of those debased)) and all the women heard her threat, and it is evident that they all informed Yousuf to obey her or else he would be jailed and humiliated. At that moment prophet Yousuf (PBUH) resorted to Allah and said: ((He said, "My Lord, prison is more to my liking than that to which they invite me)), because the human capacity and energy are not sufficient to achieve this strong infallibility, the prison is so much hated and what they invited him to is very demandable, so how does he say the hardship is more loved to him than the pleasure? The answer is that the pleasure will result in great pains represented by the contempt in this world and the punishment in the hereafter, while staying in the prison will lead to great happiness represent by praise in this world and permanent reward in the hereafter, or the implicit speech is one of two should be done; either committing adultery or entering the prison, and so the prison was the choice. When someone has to choose one of two evil things, he would choose the less evil of them which is considered a lighter burden (Fakhr AlDeen AlRazi, 1999).

\subsection{Affection and Its Derivations, Concept and Semantic Meaning}

(Wad'dah-liked): it refers to intimacy and wishing to have something, so it means intimacy and affection and the word in Arabi (Wadeed) means the person whom is loved (Ibn Faris, 2008).

\section{2 .1}

Wud (intimacy) is the name and the verb is (Wadidtu) which means I wished something to be mine and its past and future tenses are the same in the context of (Wad'da). This word cannot be used instead of love because the concept of (Wad'da = liked) is not an absolute loving, but it means love which is associated with wishes and the word is related to the conditional "if". Also (Wud) is loving something or someone and wishing to be him, Almighty Allah says ((And of His signs is that He created for you from yourselves mates that you may find tranquility in them; and He placed between you affection and mercy. Indeed in that are signs for a people who give thought)) (AlRum: 21) (AlAsfahani, 1992).

\section{2 .2}

Through reviewing the linguistic and terminological meanings of the word "affection" it was clear that there is 
some interrelation; as affection is love, but it is conditioned with wishing. Usually the word "wud" is associated with "law = if" which is used for wishing in addition to love because the verb "wad'da = liked" is not used for the absolute affection, but for the affection compared with wishing and sometimes we use the word (wud = affection) to denote love and this is for the purpose of expansion. From what has been mentioned earlier, we conclude that there are an evident semantic difference between love and affection (Hubb and wud) and a slight interrelation between them. Love is the attraction of the soul towards the item or the person it desires, so it is the willing to have what it thinks it is good. From the other hand, affection is the love that is associated with wishing, which is the will to get what the soul desires. Therefore, affection is loving and willing and this comparison is the condition to use this word originally. In addition to that love represents the feelings inside the heart, but affection (wudd) is what is apparent in the behavior and not every loving person is friendly and man can have love that doesn't show in his behavior. Every friendly person has affection established on the feelings of love which are in the heart. There is general and particular relations between the two words as affection is the pure and the mere aspect of love, therefore every affection is love and the opposite is not correct. Throughout the statistics of the word (wudd = affection) in the noble Quran, we notice that it was mentioned as the base verb (wad'da $=$ liked) and its derivations twenty six times in twenty six verses in different forms including verbs and verbal nouns. It was mentioned as verbs several times and it is of a similar meaning to the word (love) especially for the present tense verbs which was mentioned eight times, while for the past tense verb, it was mentioned six times but it was not mentioned in the imperative form for the same reason we stated in the word (love) earlier. The word was mentioned in the present tense for as follows: (Yawad'du, tawad'du, yawad'doon, tawad'doon and Yawaad'doon), the past tense for as follows: (wad'da, wad'dat and wad'doo) and the verbal noun form (Wud'da and mawad'datan).

\subsubsection{1}

Almighty Allah says: ((The Day every soul will find what it has done of good present [before it] and what it has done of evil, it will wish that between itself and that [evil] was a great distance. And Allah warns you of Himself, and Allah is Kind to [His] servants.)) (Aalu Imran: 30).The verse (it will wish that between itself and that [evil] was a great distance) denotes triggers and intimidation, and this sentence might be a trait for evil and the meaning is: for the evil it did, it will wish to be very far from it, or it may denote: in the day it will find what it did ready before it, or it might not denote intimidation and here is the location of generosity and grace, because the text denotes that the reward will be ready but no mention for the punishment but only that the sinners like to escape from that day. The (wudd = like) means wishing something desired to happen (Fakhr AlDeen AlRazi, 1999).

\subsubsection{2}

Almighty Allah says: ((That Day, those who disbelieved and disobeyed the Messenger will wish they could be covered by the earth. And they will not conceal from Allah a [single] statement.)) (AlNisaa: 42). The verse (That Day, those who disbelieved and disobeyed the Messenger wish), is a substitution for the sentence which denotes: ((In the day we bring from each nation a witness and bring you as a witness to those, That Day, those who disbelieved (Abu HayyanAlAndalusi, 1999) and the meaning of (Yawad'du) is wish; because they were surprised with something they used to deny and they didn't believe that the issue is serious. They thought that what the messenger said to them was only words, but they are surprised in the resurrection day. What will their attitude be? It is said that they be part of the earth, and another opinion is they wish to be animals which will be turned into dust (AlShaarawi, 1997) and (And they will not conceal from Allah a [single] statement), that means they will not conceal from Allah even a single statement as they unable to do that as all their organs, hands and legs will testify what they did and that will be their confession of sins which leads them to the fire (AlAloosi, 1995).

\subsubsection{3}

Almighty Allah says: ((A faction of the people of the Scripture wishes they could mislead you. But they do not mislead except themselves, and they perceive [it] not)) (Aalu Imran: 69).The verse ((A faction of the people of the Scripture wish)), the word (wad'dat) means wished and liked. So, why do they like to mislead the believers? They do so because when the deviant, when he see the righteous person, knows that he himself couldn't adjust himself in accordance with the faith assignment of (do) and (don't do). For the committed believer, he could adjust himself as a committed person. When the person who is uncommitted sees a committed person, he will despise himself and wonders: why and how could this committed man discipline himself and so he tries to make him deviant to be like him (AlShaarawi, 1997). It was said that the people of scripture are the Jews and also said that they are the both parties (Christians and Jews) and the verse states that they are the callers to astray, and the article $($ law $=$ if) denotes wishing. The implicit meaning of the sentence is: they liked to make you astray for this 
they will be pleased, but they only astray themselves and they deserved the wrath and anger of Allah as they wish to perish the believers (AlAloosi, 1995). Another similar verse is: ((Many of the People of the Scripture wish they could turn you back to disbelief after you have believed, out of envy from themselves)) (AlBaqara: 109). And the verse: ((They wish you would disbelieve as they disbelieved so you would be alike)) (AlNisaa: 89).

\subsubsection{4}

Almighty Allah says: ((And of His signs is that He created for you from yourselves mates that you may find tranquility in them; and He placed between you affection and mercy. Indeed in that are signs for a people who give thought.)) (AlRoom: 21). In this verse: tranquility needs two elements: the calmness and peacefulness and the meaning is the wife. If the place in which you dwell loses one of these two elements it will lose its meaning. The good wife was described as the home which is full of affection, mercy and grace. The sentence (you may find tranquility in them) is the main purpose of marriage, i.e. the two spouses find tranquility with the each other and tranquility comes after the tiredness and toil at the end of a long day of work the husband returns home to find his wife who comforts him and overwhelms him with tenderness, kindness and gentleness. When the husband receives that, he rests and regains his activity for the next day work. In addition to all that (He placed between you affection and mercy), affection is the exchanged love in life as the husband works hard to earn the living for the family and the wife works hard at home and raise her children and this is the framework of love exchange and tenderness. For mercy, it comes at the end as the circumstances of a human may change, a strong person becomes weak, the rich might become poor, a beautiful woman is changed by age, and for this reason the Holy Quran draws our attention to the stage in which the spouses could lose the home and affection but they still have mutual mercy. The husband be merciful with his wife and the wife be the same if her husband got sick or became poor. If the apparent beauty vanished with time the beauty and the dignity of the soul remains, and Allah created our spouses from ourselves and not from another species (AlShaarawi, 1997). Eve either was created by Allah from the rib of Adam or from your species and the reason of creation of spouses is to resort to each other with tranquility and so the affection between the two spouses with different genders exists. On the contrary between the same gender there will be repulsion. Moreover, there will be affection and mercy between the two spouses although they have no acquaintance between them before that requires to result in affection and mercy (Abu Hayyan AlAndalusi, 1999).

\subsubsection{5}

Almighty Allah says: ((Indeed, those who have believed and done righteous deeds - the Most Merciful will appoint for them affection)) (Meriam: 96). In this verse (The Most Merciful will appoint for them affection) refers to the pleasure of the believers when they know that Allah will make affection to them, which means: the people will love them in this world without being their relatives or kin, friendship or favor but because they are believers who do good deeds and their enemies will fear them, i.e. Allah promised to spread love in their hearts in this world and made them beloved to his creations in the hereafter by telling about their good deeds to all the creatures. The letter ( $\omega=$ will) denotes either that the Sura has descended in Mecca when the believers were hated by the disbelievers, therefore Allah promised them or Allah means at the judgment day Allah will make them beloved to his creatures by manifesting their good deeds (AlShafi'ee, 2001). So, the letter ( w = will) is not for emphasizing the present tense verb it is attached to but to denotes future only (Abu Hayyan AlAndalusi, 1999). The (wudd $=$ affection) is a psychological emotion which is full of love feelings and it is stronger than love and more attached to the soul than love (Ibrahim, 2009).

\section{2 .3}

From what has been mentioned earlier, it is clear to us that affection is the pureness of love which is mingled with wishing and the exchange of love acts whether between a husband and a wife or all the people who feel affection. When Almighty Allah created affection for the believers, this will make everything easier for them besides receiving them very warmly.

\section{Conclusion}

There is a clear semantic difference between "love" and "affection" and a slight interrelation between them. Love is the attraction of the soul to something it desires and it is the willing to have what the soul considers or believes that it is good. From the other hand, affection is to like something or someone and wishes to be that one. This comparison is the condition of using it originally, in addition to that, love is feeling inside the heart and these feelings may not appear in the behavior of the person, while the affection appears in the acts of the person and so there is a sign of generality and particularity as the affection is considered love and the contrary is not right. 
The word "love" and its derivations was mentioned in the context of willing, persistence and accompanying, while the word "affection" was used associated with wishing and accompanies the verbs exchanged by the two parties and for this reason the word "love" was mentioned in the duality of (love /doesn't love) by Almighty Allah as He wants to beneficial to his slaves (humans), pleased with them, merciful and forgiving, and nothing should be wished from Allah because if He wants something to be, He says to it be and it is created.

\section{References}

Al-Aloosi, Sh. M. (1995). Rooh Al-Maani Fi Tafseer Al-Quran Al-Atheem WalSab'ul Mathani (1st ed.).

Al-Andalusi, M. Y. (1999). Al-Bahr Al-Muheet Fil Tafseer. Beirut, Lebanon.

Al-Asfahani, H. M. (1992). Vocabularies in the strange words in Quran (1st ed.). Beirut, Lebanon.

Al-Fairooz Abadi, M. Y. (1996). Basair Thawi Al-Tam'yeez Fi Lataif Al-Kitab Al-Aziz. Cairo. Egypt.

Al-Nabulsi. M. R. Love throughout the holy quran. The official website of Sheik Mohammed Ratib Al-Nabulsi. Retrieved from http://www.nabulsi.com/blue/ar/art.ph.

AlRazi, A. F. (2008). Maqaees AlLugha (2nd ed.). Beirut, Lebanon.

Al-Razi, M. A. (1999). Mafateeh Al-Ghayb (3rd ed.). Beirut, Lebanon.

Al-Saimari. M. A. (2002). The derivatives constructs in NahjAlBalaghah Book, Rhetorical study (Unpublished M. A. thesis), Basrah University. Iraq.

Al-Samaraee. F. S. (2007). The meanings of constructs in Arabic (1st ed.). Mosul. Iraq.

Al-Samaraee. F. S. (2007). The meanings of Grammar (1st ed.). Beirut, Lebanon.

Al-Shaarawi, M. M. (1997). Al-Shaarawi Interpretation of Quran (Al-Khawatir). Egypt, Cairo: Akhbar Al-Yawm press houses.

AlShafiee, M. A. (2001). Tafseer Hada'iq Al-Rawh Wal Rayhan Fi Rawabi Uloom Al-Quran. Beirut. Lebanon.

Al-Sharafi, A. A. (2014). Love and hatred in the light of the Holy Quran (Master Thesis). Islamic University, College of Religion Fundamentals, Ghazza, Palestine.

Al-Thallab, S. H. A., \& Jawad, H. (2015). Love in the holy quran (the duality of love/doesn't love). Tikrit University, Iraq.

Al-Zamakhshari, M. A. A. (1987). Al-Kashaf An Haqaiq Ghawamidh (3rd ed.). Beirut, Lebanon.

Dawood, M. M. (2008). Dictionary of semantic differences in the Holy Quran. Cairo.

Ibn-Manthoor, J. M. (2003). Lisan Al-Arab (A revised edition by an elite of specialists), Cairo, Egypt.

Ibrahim, Z. H. (2009). Words of the soul states and their description in the Holy Quran (A published master thesis). Al-Najah National University, Higher studies College, Palestine.

Ukasha, M. (2005). Linguistic analysis in the light of Semantics (1st ed.). Cairo, Egypt.

Yaseen Z. H. A. (2009). Words that denote the mood of the soul and its characteristics in the Holy Quran. Al-Najah National University, Palestine.

\section{Copyrights}

Copyright for this article is retained by the author(s), with first publication rights granted to the journal.

This is an open-access article distributed under the terms and conditions of the Creative Commons Attribution license (http://creativecommons.org/licenses/by/4.0/). 